\title{
Planetary Waves in the Upper Stratosphere in Early 1966*
}

\author{
By Isamu Hirota \\ Geophysical Institute, Tokyo University, Tokyo \\ (Manuscript received 18 July 1968, in revised form 8 November 1968)
}

\begin{abstract}
Analyses of the structure and behavior of planetary waves in the upper stratosphere are made by the use of the meteorological rocket observations together with the daily stratospheric synoptic charts during the period of 1966 wintertime. The vertical time-sections of temperature for Fort Greely, Fort Churchill and other stations indicate that large-scale disturbances exist in the higher latitudes extending vertically from the lower to the upper stratosphere. The vertical cross sections of temperature along $60^{\circ} \mathrm{N}$ also indicate the evidence of planetary-scale wavelike disturbances characterized by the westward tilting of isotherms, as well as the trough axis, with increasing height.

The separation of traveling planetary waves from the standing wave is made by taking time derivatives of temperature along $60^{\circ} \mathrm{N}$. The results show the existence of eastward moving waves of wave number two and westward moving waves of wave number one. The downward propagation of temperature phase as indicated by the vertical time-section at a given station is related to the westward movement of wave disturbances.

Finally discussion is extended to the relationship between the behavior of transient waves and the time variation of zonal wind in terms of stability properties of polar night westerlies.
\end{abstract}

\section{Introduction}

It is well known that the stratospheric circulation in wintertime is characterized by the pronounced polar night westerlies in the high latitudes and that a drastic deformation of the polar vortex takes place in mid-winter or in late winter due to the development of planetary-scale disturbances associated with the sudden warming. Following the discovery of the sudden warming by Scherhag (1952), a number of studies have been made from various standpoints based upon the data of high altitude balloon observations in the hemispheric scale. In early papers by Warnecke (1956), Teweles (1958), Craig and Hering (1959) and others the warming phenomenon was investigated synoptically. Efforts have also been made to explain the phenomenon as a manifestation of a kind of dynamical instability associated with the polar night westerlies in the stratosphere (Murray, 1960: Charney and Stern, 1962; Matsuno and Hirota, 1966: Hirota, 1967a).

In a previous paper (Hirota, 1967b), the author

\footnotetext{
* Division of Meteorology, Contribution No. 168.
}

has presented a vertical structure of temperature field of the stratosphere and its time variation throughout the period of the sudden warmings of 1958,1963 and 1965 by making the vertical cross sections along $50^{\circ} \mathrm{N}$ from $300 \mathrm{mb}$ up to $10 \mathrm{mb}$. The conclusions obtained from the analyses are that the "warming" first appears in a lower level, say $100 \mathrm{mb}$, and propagates upward to about the $10-\mathrm{mb}$ level and then the disturbance starts to retrograde in the westerly current in association with the breakdown of the polar vortex. Moreover it was shown that the " downward propagation" of the warming which appeared in the vertical time-section at a given station is a result of the westward movement of the disturbance whose phase lines are tilted westward with increasing height. These results suggest that the structure and behavior of the planetary-scale disturbance, and its upward propagation, are closely related to the stratospheric sudden warming.

The description mentioned above was limited to the middle and lower stratosphere below the $10-\mathrm{mb}$ level based on the conventional rawinsonde observations. However, recent progress of the 
meteorological rocket network (MRN) makes it possible to describe the characteristic feature of the upper stratosphere (and sometimes of the lower mesosphere) below 60 or $70 \mathrm{~km}$ by virtue of rocketsonde wind and temperature measurements. Fig. 1 shows the distribution of rocketsonde stations. Most of them are concentrated in North America.

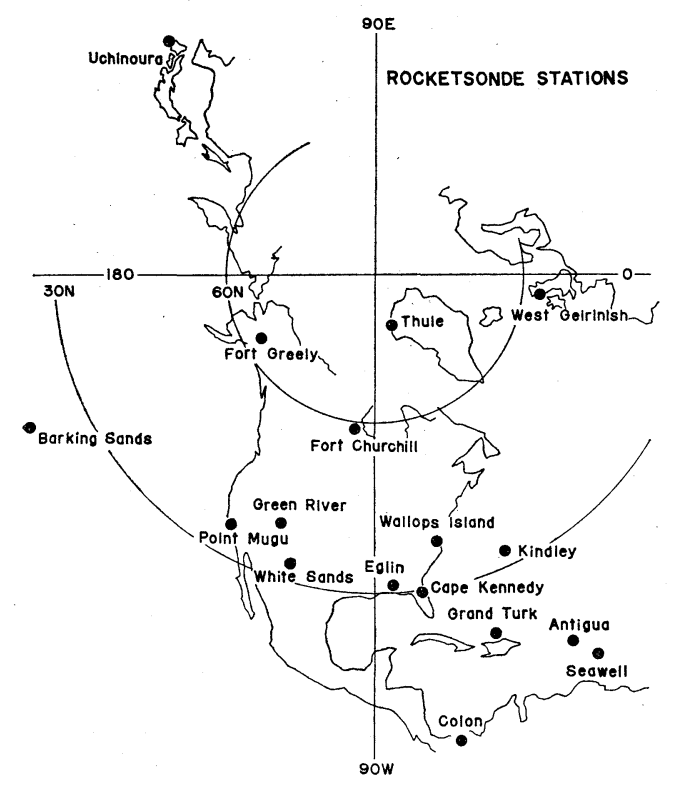

Fig. 1. Geographical location of Meteorological Rocket Network stations.

Synoptic analysis of the upper stratospheric circulation based on meteorological rocketsonde data was first attempted by Finger, Teweles and Mason (1963). They investigated the feasibility of applying rocketsonde data in the synoptic analysis of the circulation and temperature fields in the upper stratosphere and presented patterns over the North American area at $2 \mathrm{mb}$ (approximately $42 \mathrm{~km}$ ) and $0.4 \mathrm{mb}$ (approximately $55 \mathrm{~km}$ ) for several selected days from 1960 to 1962.

Finger and Teweles (1964) have drawn vertical time-sections of winds up to $60 \mathrm{~km}$ for Cape Kennedy, Wallops Island, White Sands and Point Mugu throughout the period of the 1963 JanuaryFebruary warming, and shown the downward propagation of the phase of winds at each station. They have further shown some synoptic charts of the 2- and 0.4-mb levels, which indicate the deformation of the polar vortex in the upper stratosphere in mid-winter. Synoptic analyses of the 5-, 2-, and $0.4-\mathrm{mb}$ surfaces by the use of rocket data have been attempted extensively also by Finger, Woolf and Anderson (1966) on a weekly basis for the IQSY period. They have discussed the method of correction of rocket data in comparison with conventional rawinsonde data. Finger and Woolf (1967) investigated the Southern Hemispheric circulation by utilizing the meteorological rocket data of the NASA Mobile Launch Expedition.

The inspection of these synoptic charts reveals that the planetary-scale wave disturbance is predominant in the upper stratosphere and varies gradually with a time scale of one week or so. Studies on planetary waves in the stratosphere based on the spherical harmonic analysis of the geopotential field up to $10 \mathrm{mb}$ have been made by Boville (1966), Deland and Johnson (1968). The study of the structure and behavior of planetary waves in the upper stratosphere and lower mesosphere using similar methods is, however, very difficult to make, because the data density of MRN is too sparse both in time and space.

The main purpose of the present study is to investigate the structure and behavior of planetary waves by means of time and space cross sections of temperature and winds from $10 \mathrm{~km}$ to $60 \mathrm{~km}$. Since we are interested in the dynamics of planetary waves in the polar night westerlies, a qualitative discussion is extended to the interrelation between the behavior of waves and the time change of the zonal mean wind in the middle and lower stratosphere.

\section{Data}

The data report of meteorological rocket network firings of 1966 published by World Data Center $\mathrm{A}$ is used in the present study. Original data of rocketsonde observations from West Geirinish, Scotland, are added to the analysis. Table 1 shows an example of the meteorological rocket network summary indicating date and time of firings, types of rocket wind and temperature sensors, and temperature and wind tracking.

Daily northern hemispheric synoptic charts of 5-, 10-, 30-, 50- and 100-mb levels published by Free University of Berlin are also available. In drawing vertical time-sections and cross sections, rocketsonde data and rawinsonde data are combined together and smoothed in the region from $20 \mathrm{~km}$ to $35 \mathrm{~km}$. 
Table 1. An example of the meteorological rocket network summary.

\begin{tabular}{|c|c|c|c|c|c|c|}
\hline $\begin{array}{l}\text { Date } \\
\text { GCT }\end{array}$ & $\begin{array}{l}\text { Time } \\
\text { GCT }\end{array}$ & $\begin{array}{l}\text { Type } \\
\text { Rocket }\end{array}$ & $\begin{array}{l}\text { Wind } \\
\text { Sensor }\end{array}$ & $\begin{array}{c}\text { Temperature } \\
\text { Sensor }\end{array}$ & $\begin{array}{l}\text { Temp Track } \\
\left(10^{1} \text { M MSL }\right)\end{array}$ & $\begin{array}{l}\text { Wind Tranck } \\
\left(10^{1} \mathrm{M} \text { MSL }\right)\end{array}$ \\
\hline \multicolumn{5}{|c|}{ FORT GHURCHILL, CANADA } & \multicolumn{2}{|c|}{ Lat. $\quad 58^{\circ} 44^{\prime} \mathrm{N}$ Long. $93^{\circ} 49^{\prime} \mathrm{W}$} \\
\hline 5 Jan 66 & 1800 & Arcas & Chute & Arcasonde $1 \mathrm{~A}$ & $5837-2426$ & $4975-2425$ \\
\hline $7 \mathrm{Jan} 66$ & 1900 & Arcas & Chute & N/A & $\mathrm{N} / \mathrm{A}$ & $5115-2450$ \\
\hline 14 Jan 66 & 1800 & Arcas & Chute & Arcasonde $1 \mathrm{~A}$ & $5615-2312$ & $5105-2310$ \\
\hline 17 Jan 66 & 1800 & Arcas & Chute & Arcasonde $1 \mathrm{~A}$ & $5265-2200$ & $5535-2340$ \\
\hline $21 \mathrm{Jan} 66$ & 2230 & Arcas & Chute & $\mathrm{N} / \mathrm{A}$ & $\mathrm{N} / \mathrm{A}$ & $5155-2400$ \\
\hline 24 Jan 66 & 0640 & Arcas & Chute & Arcasonde 1A & $5560-2281$ & $5430-2309$ \\
\hline \multicolumn{5}{|c|}{ FORT GREELY, ALASKA } & \multicolumn{2}{|c|}{ Lat. $64^{\circ} 00^{\prime} \mathrm{N}$ Long. $145^{\circ} 44^{\prime} \mathrm{W}$} \\
\hline $8 \mathrm{Jan} 66$ & 2100 & Arcas & Chute & Arcasonde $1 \mathrm{~A}$ & $5520-1849$ & $5044-1881$ \\
\hline 9 Jan 66 & 2000 & Arcas & Chute & $\mathrm{N} / \mathrm{A}$ & N/A & $5204-1875$ \\
\hline 10 Jan 66 & 2000 & Arcas & Chute & Arcasonde $1 \mathrm{~A}$ & $5537-1800$ & $5206-1826$ \\
\hline 11 Jan 66 & 2000 & Arcas & Chute & Arcasonde $1 \mathrm{~A}$ & $4017-1834$ & $4473-1879$ \\
\hline 16 Jan 66 & 2000 & Arcas & Chute & Arcasonde $1 \mathrm{~A}$ & $5580-1901$ & $5538-1884$ \\
\hline 17 Jan 66 & 2000 & Arcas & Chute & Arcasonde $1 \mathrm{~A}$ & $5505-1918$ & $5063-1867$ \\
\hline 20 Jan 66 & 2007 & Arcas & Chute & Arcasonde $1 \mathrm{~A}$ & $6311-3556$ & $4889-1831$ \\
\hline 28 Jan 66 & 2000 & Arcas & Chute & Arcasonde $1 \mathrm{~A}$ & 5915-2030 & $5564-1774$ \\
\hline 29 Jan 66 & 2003 & Arcas & Chute & Arcasonde $1 \mathrm{~A}$ & $5595-1870$ & $5453-1864$ \\
\hline 30 Jan 66 & 2030 & Arcas & Chute & $\mathrm{N} / \mathrm{A}$ & N/A & 5394-1892 \\
\hline
\end{tabular}

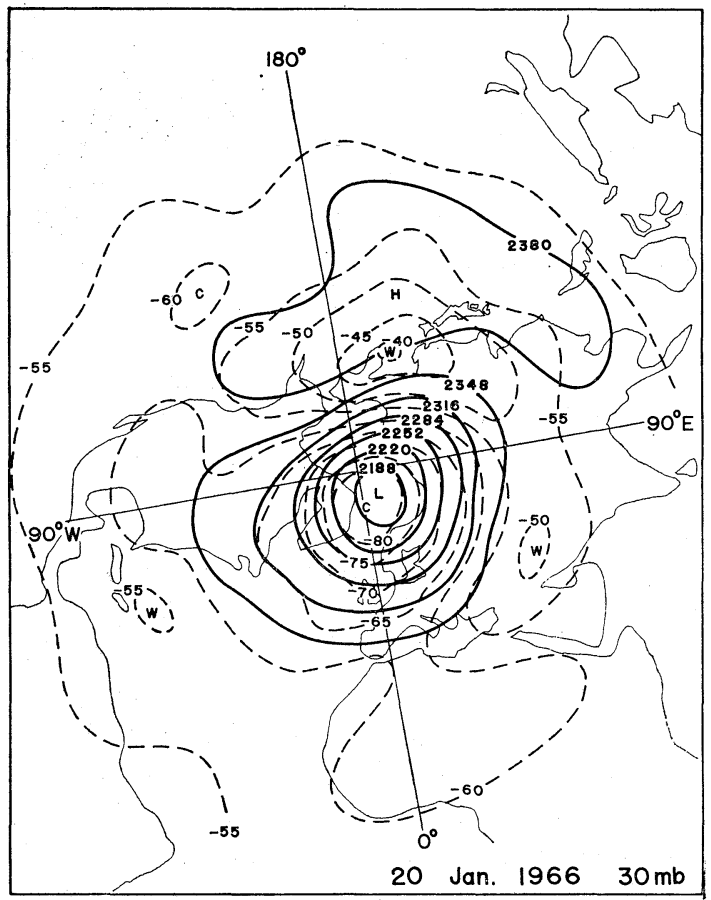

(a)

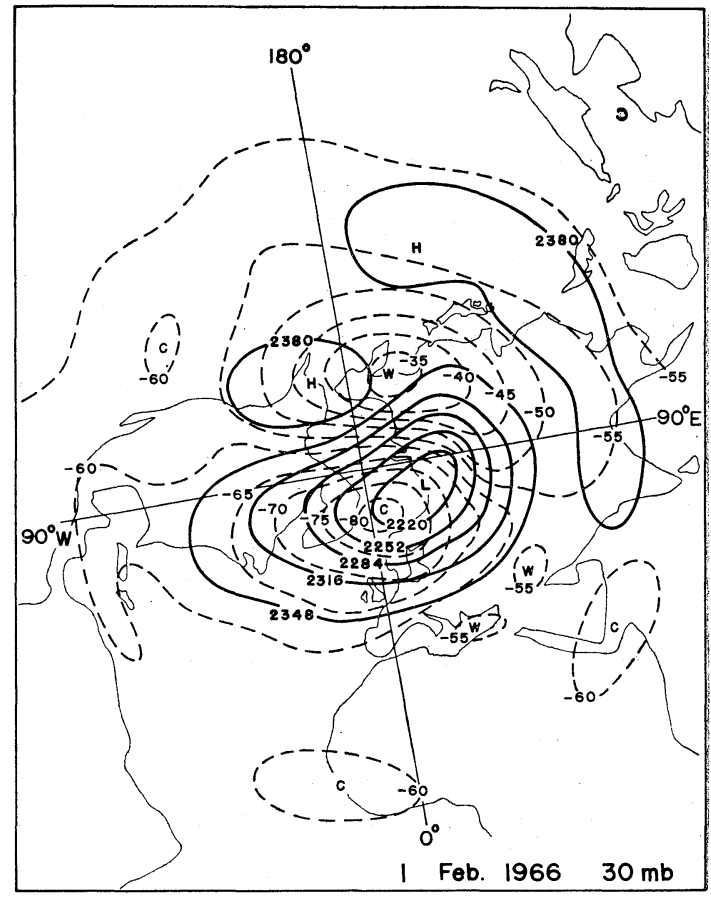

(b)

Fig. 2. $30 \mathrm{mb}$ synoptic chart on $20 \mathrm{Jan} .1966$ (left) and on 1 Feb. 1966 (right). Units in decameter (height) and ${ }^{\circ} \mathrm{C}$ (temperature). 


\section{Stratospheric circulation in early 1966}

Brief description is given on the synoptic characteristics of 1966 mid-winter stratospheric circulation. Fig. $2 \mathrm{a}$ and $2 \mathrm{~b}$ show the synoptic charts at $30 \mathrm{mb}$ on 20 January and 1 February, 1966, respectively. The mid-stratospheric circulation in this period is characterized by a well developed circumpolar vortex closely related to the cold region, temperature over Greenland being about $-80^{\circ} \mathrm{C}$ at the $30-\mathrm{mb}$ level. On the contrary, temperature of the warmer region on the western portion of the Aleutian High exceeds $-30^{\circ} \mathrm{C}$. Throughout the period of January and February in 1966 neither a major warming nor a breakdown of the polar vortex takes place in the middle stratosphere, but minor warmings at the 30 - and $10-\mathrm{mb}$ levels are observed twice on about 17 January and 31 January in the high latitudes in the eastern hemisphere. Another warming is observed on about 23 February over Europe. Labitzke (1968) has presented some characteristics of the 1966 warmings using the radiosonde observations over Berlin above $30 \mathrm{~km}$ together with the northern hemispheric synoptic charts up to the $5-\mathrm{mb}$ level.

In short, the stratospheric circulation of the 1966 winter is characterized by minor warmings of moderate intensity embedded within the flow and temperature patterns which show gradual time changes for a relatively long time.

\section{Vertical time-sections of temperature}

Vertical time-sections of temperature as indicated by rocketsonde data and rawinsonde data are presented in this section for four stations of Fort Greely, Alaska $\left(64^{\circ} 00^{\prime} \mathrm{N}, 145^{\circ} 44^{\prime} \mathrm{W}\right)$ Fort Churchill, Canada $\left(58^{\circ} 44^{\prime} \mathrm{N}, 93^{\circ} 49^{\prime} \mathrm{W}\right)$, West Geirinish, Scotland $\left(57^{\circ} 21^{\prime} \mathrm{N}, 07^{\circ} 22^{\prime} \mathrm{W}\right)$ and Point Mugu, California $\left(34^{\circ} 07^{\prime} \mathrm{N} 119^{\circ} 07^{\prime} \mathrm{W}\right.$ ). (See Fig. 1) The first three stations (Greely, Churchill and Geirinish) are located nearly along the latitudinal circle of $60^{\circ} \mathrm{N}$. Point Mugu is chosen as an example of the station in the subtropical region.

Before proceeding to the discussion of the results of analyses of rocket data, we should make comments on the diurnal variations of temperature and wind. The diurnal variation of temperature due to absorption of solar radiation and infrared emission by molecules in the upper atmosphere was discussed by Leovy (1964). He has shown the range of diurnal temperature change as a function of height and latitude, indicating that the maximum amplitude of temperature change is of the order of $3^{\circ} \mathrm{C}$ in the higher latitudes, say $60^{\circ} \mathrm{N}$. Observations of diurnal temperature change in the stratosphere were done by Beyers and Miers (1965) over White Sands Missile Range $\left(32^{\circ} \mathrm{N}\right)$. According to their results the diurnal temperature range is less than $5^{\circ} \mathrm{C}$ below $40 \mathrm{~km}$ and about $10^{\circ} \mathrm{C}$ near the stratopause, though these values are somewhat larger than Leovy's theoretical results. Concerning the diurnal variation of wind, Reed et al. (1966) have presented north-south cross sections of meridional wind component, indicating that the maximum amplitude of wind variation near the stratopause is less than 10 meter/second. The range of temperature and wind variations in which we are interested in the present study is significantly greater than that of diurnal variations. Moreover most of the stations used in our study are located in higher latitudes and most of rocket firings at these stations are made at about local noon. We may therefore safely disregard the effect of diurnal variations in the present analyses.

Fig. 3 shows the vertical time-sections of temperature at four stations throughout the period of 1966 wintertime. In this figure the ordinate denotes the height from $10 \mathrm{~km}$ up to $60 \mathrm{~km}$ (approximately from $250 \mathrm{mb}$ to $0.2 \mathrm{mb}$ ) and the abscissa denotes the dates from January to April. Solid circles on the abscissa indicate that the rocketsonde data are available. Looking at the figures we first find a gradual increase of temperature in the upper stratosphere with the progress of season. Embedded within the general increase of temperature we find a marked temperature disturbance from the end of January to the beginning of February, which extends vertically from $20 \mathrm{~km}$ up to $60 \mathrm{~km}$. The similarity of the time section at Fort Greely with that at Fort Churchill in this period suggests that the disturbance extends in the east-west direction. Unfortunately, no data is available until 8 February at West Geirinish (Fig. 3c), but a pronounced temperature disturbance is observed also at this station on about 10 February. Moreover it should be remarked that the phase propagation of temperature observed at Ft. Greely and Ft. Churchill in February is directed downward with a speed or about $6 \mathrm{~km} /$ day. On the contrary, 


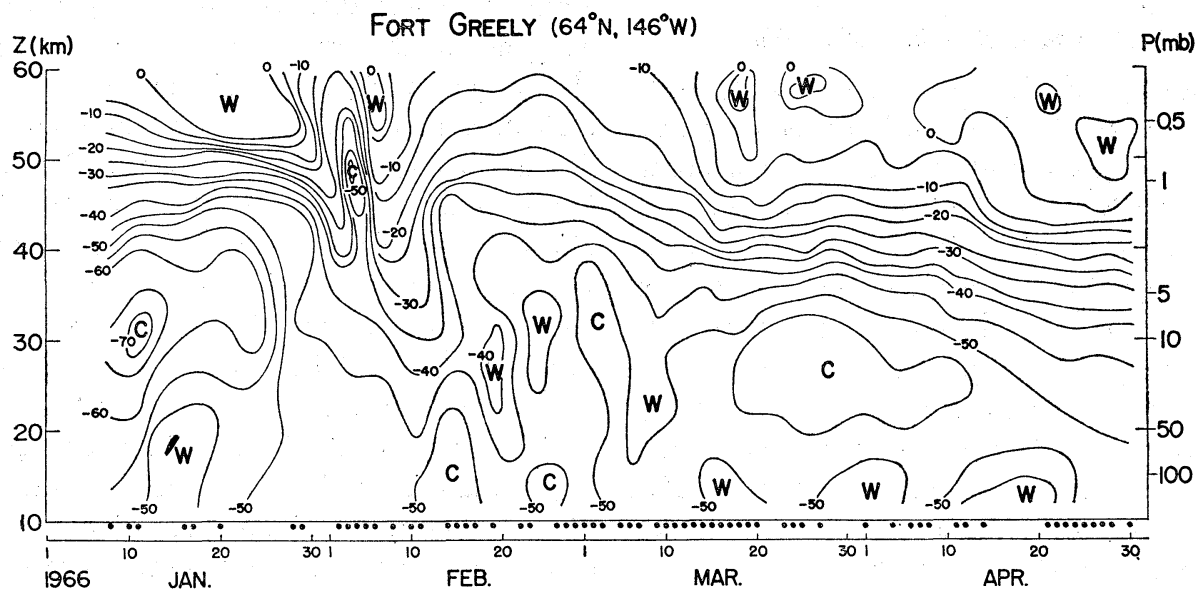

(a)



(b)

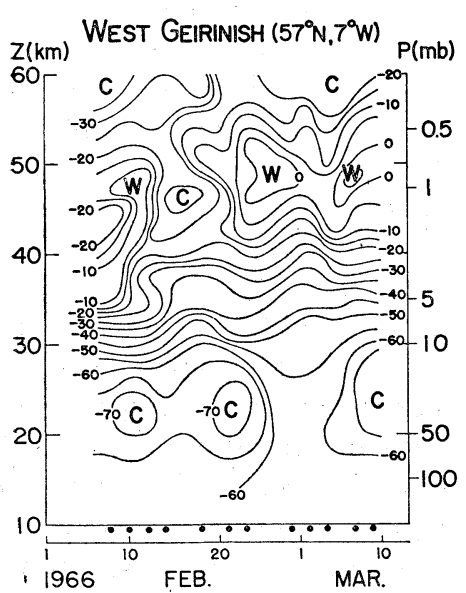

(c)

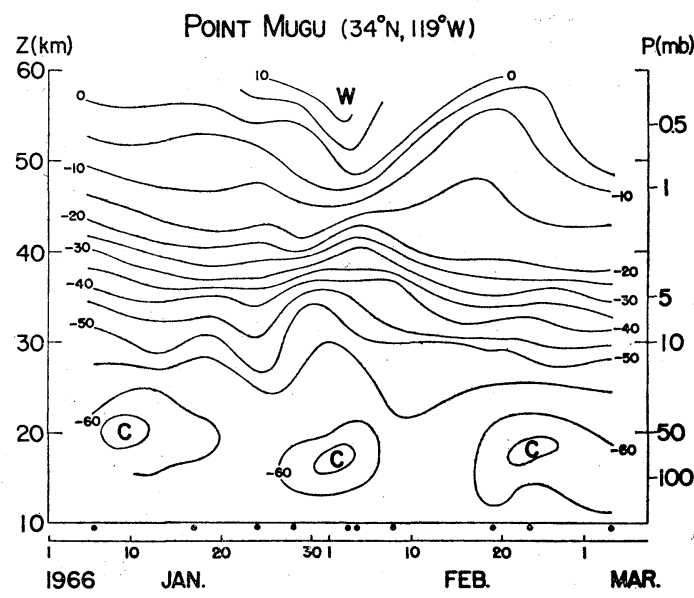

(d)

Fig. 3. Vertical time-sections of temperature at Fort Greely (3a), Fort Churchill (3b), West Geirinish (3c) and Point Mugu (3d), Units in ${ }^{\circ} \mathrm{G}$. Solid circles on the abscissa denote that the rocketsonde data are available. 
the time section of Point Mugu (Fig. 3d) shows that the temperature change observed on about 5 February is very small compared with that of Greely and Churchill. Therefore it appears that the stratospheric disturbance under consideration has a large amplitude in the higher latitudes and is wavelike along the latitudinal circle. The wave structure will be substantiated in following sections.

Before we leave this section, a summary of the temperature data of this period at Ft. Greely is shown in Fig. 4. On the left of Fig. 4, monthly mean temperature distributions from

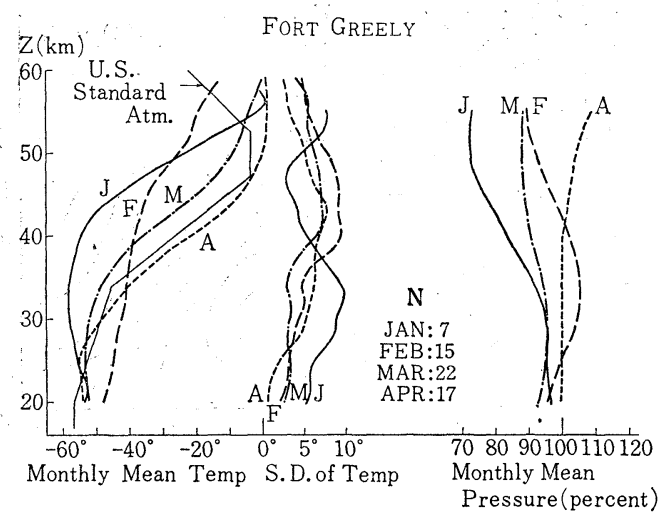

Fig. 4. Veritcal distribution of monthly mean temperature from January to April in 1966 at Fort Greely (left), standard deviation of temperature (middle) and monthly mean pressure (right). $\mathrm{N}$ indicates the number of available data.

January to April are shown in comparison with that of the U.S. Standard Atmosphere. It is easily found that the vertical distribution of temperature gradually approaches to that of the standard atmosphere from January to March and April, whereas in February it differs from others, showing an anomalous warming below $40 \mathrm{~km}$ and a cooling above $50 \mathrm{~km}$. The standard deviation of daily temperature values for each month is shown in the middle of the figure where $\mathrm{N}$ indicates the number of data used for calculating the standard deviation. We find that the temperture variation is predominant in the middle stratosphere for January and in the upper stratosphere for other months. The significant difference of the vertical distribution of the standard devia. tion between January and February may be related to the intermittent upward propagation of large-scale disturbances in January. On the right of Fig. 4, the ratios of monthly mean pressure to that of the U.S. Standard Atmosphere are presented. Anomalous high pressure is. observed in February in accordance with the anomalous temperature distribution mentioned above. Statistical properties of temperature: variations for other stations are not presented. here because of the sparsity of rocketsonde data.

\section{Cross sections of temperature}

In order to substantiate the existence of wavelike disturbances in the stratosphere in the higher latitudes, we have prepared vertical cross. sections of temperature along the latitudinal circle of $60^{\circ} \mathrm{N}$ throughout the period from 21 January to 10 February on every five days. Fig. 5 shows the cross sections of temperature where the ordinate indicates the height from 10 $\mathrm{km}$ to $50 \mathrm{~km}$ and the abscissa the longitudes. along $60^{\circ} \mathrm{N}$. Below $35 \mathrm{~km}$ (nearly the 5 -mb level) the daily synoptic charts at the levels of 5,10 , 30,50 , and $100 \mathrm{mb}$ are used and the rocket data from Fort Greely $\left(146^{\circ} \mathrm{W}\right)$ and Fort Churchill $\left(94^{\circ} \mathrm{W}\right)$ are added above $30 \mathrm{~km}$ without any modifications, though these stations are not located at the exact $60^{\circ} \mathrm{N}$ latitude. Rocket data of West Geirinish $\left(07^{\circ} \mathrm{W}\right)$ are also added to the analysis for 10 February but without delineation of isotherms (Fig. 5e). The characteristic features. of the thermal structure shown in the cross section are as follows;

(1) Generally speaking, there is a large-scale disturbance of wave number one. The warm region is located around $150^{\circ} \mathrm{E}$, i.e., at the western portion of Aleutian High and the cold region is centered around $50^{\circ} \mathrm{W}$, i.e., at the western portion of North Atlantic Low.

(2) The inclination of isotherms is westward with increasing height. The rocketsonde data. at Greely and Churchill show that isotherms. are smoothly connected with those in the middle and lower stratosphere, and that the inclination of isotherms is also observed in the upper stratosphere. The rocketsonde data at West Geirinish on 10 February (Fig. 5e) are also consistent with other data.

(3) The longitudinal positions of the warm and cold centers are quasi-stationary during. the analysis period. This fact suggests the existence of a standing planetary wave.

The wavelike structure of temperature field $\mathrm{in}_{*}$ 


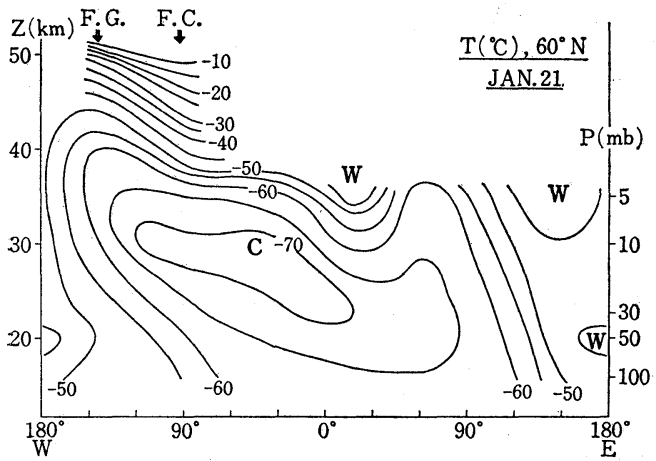

(a)

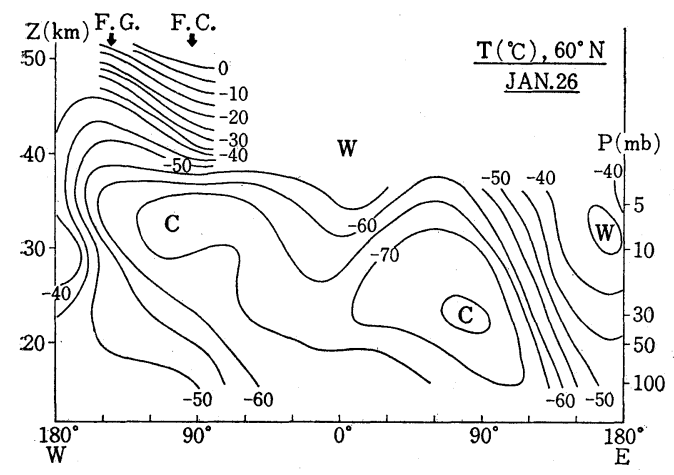

(b)

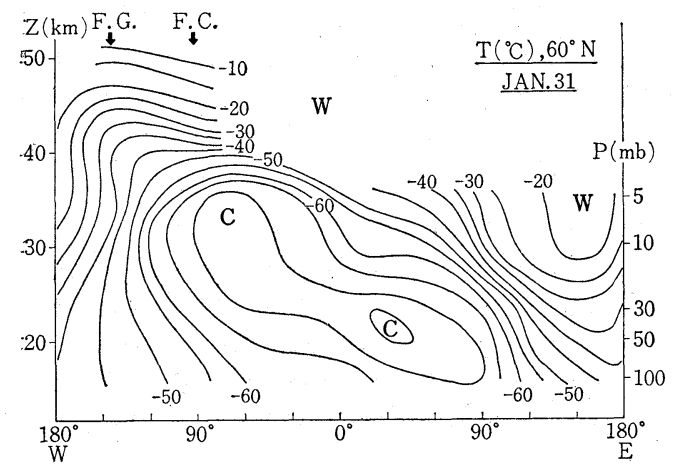

(c)

the vertical cross section indicates not only the existence of the vertical wind shear of the meridional component due to the horizontal temperature gradient but also the westward tilt of trough axis with increasing height. In order to show the westward tilt of the trough axis, we have drawn the vertical cross section of height anomalies along $60^{\circ} \mathrm{N}$ by the use of the monthly mean values of January 1966. In Fig. 6, full lines indicate the deviation of height from zonal mean values measured in meters and broken lines denote the trough axes. Solid circles indicate the

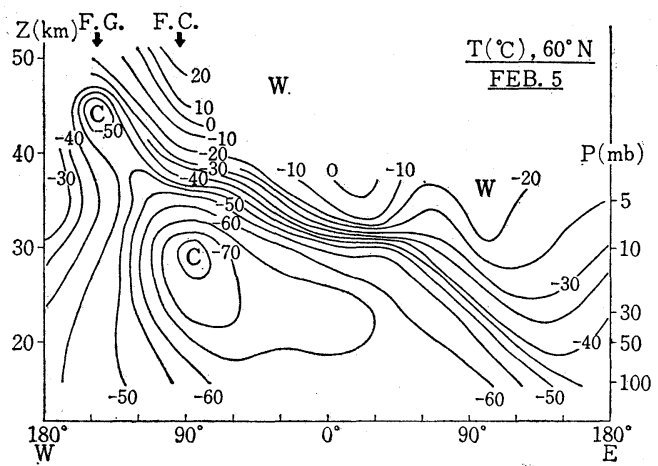

(d)

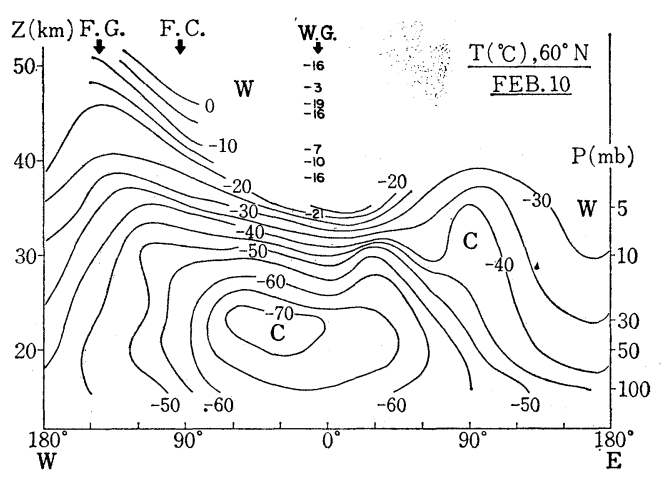

(e)

Fig. 5. Vertical cross section of temperature along $60^{\circ} \mathrm{N}$. Units in ${ }^{\circ}$ C. F.G., F.C., and W.G. denote rocketsonde stations Fort Greely, Fort Churchill and West Geirinish respectively.

positions of trough of the wave of wave number one calculated by the harmonic analysis of the monthly mean values of height at each level. On the upper left of this figure the monthly mean values of meridional winds at Fort Greely and Fort Churchill are shown, where positive values denote the southerly wind. It is easily found from the geostrophic relation that the position of trough axis is located somewhere between these two stations in the upper stratosphere and is smoothly connected with that in the middle stratosphere, showing the westward tilt of 


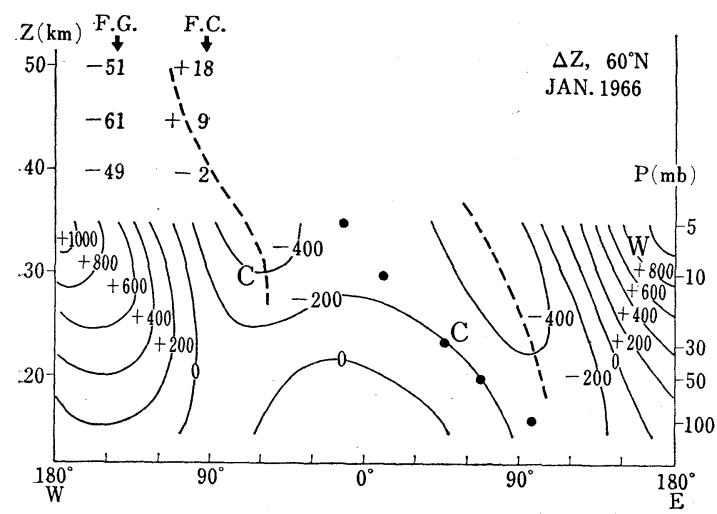

Fig. 6. Vertical cross section of monthly mean values of height anomalies (full lines) along $60^{\circ} \mathrm{N}$ for January 1966 . Units in meters. Broken lines denote trough axes and solid circles positions of the trough of wave number one. Figures below F.G. (Ft. Greely) and F.G. (Ft. Churchill) denote the monthly mean values of meridional winds. Units. in meter/sec. $\mathrm{W}$ and $\mathrm{C}$ denote the warm and cold centers.

the trough axis with increasing height.

In order to show the vertical distributions of the meridional winds at Greely and Churchill in more detail, we have drawn the vertical timesection of meridional winds. In Fig. 7 one can find the striking contrast between these two stations as to the vertical distribution of meridional winds. Namely, at Fort Greely pronounced northerly winds are observed in the upper stratosphere and southerly winds in the lower stratosphere, whereas at Fort Churchill southerly winds are observed in the upper layer and northerly winds in the lower layer. Thus it can be concluded that the large-scale wave disturbance extends from the lower to the upper stratosphere characterized by the westward tilt of the trough axis as well as that of the temperature phase.

Moreover Fig. 7 shows other interesting aspects concerning the variation of meridional wind distribution. One is the intermittent increase of the wind velocity from 10 January to 10 February with a period of about 15 days or so and the other is the breakdown of the situation mentioned above after 10 February at Fort Greely, showing the periodic oscillation of northerly and southerly winds. It should be noted that the quasi periodic oscillation of meridional winds is fairly coincident
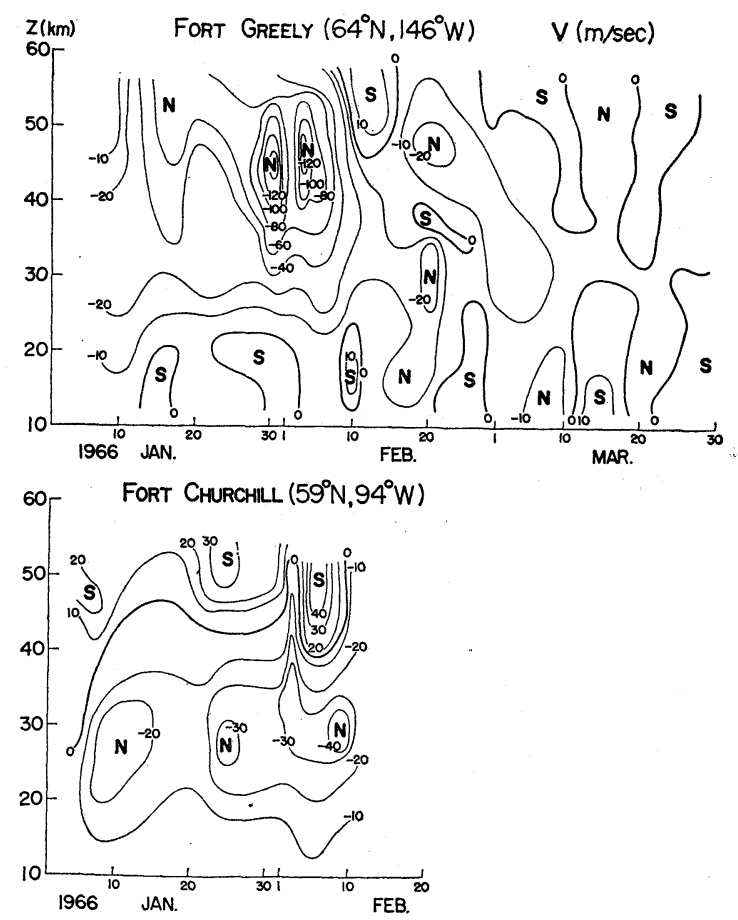

Fig. 7. Vertical time-section of meridional wind component at Fort Greely (upper) and Fort Churchill (lower). Units in meter/sec.

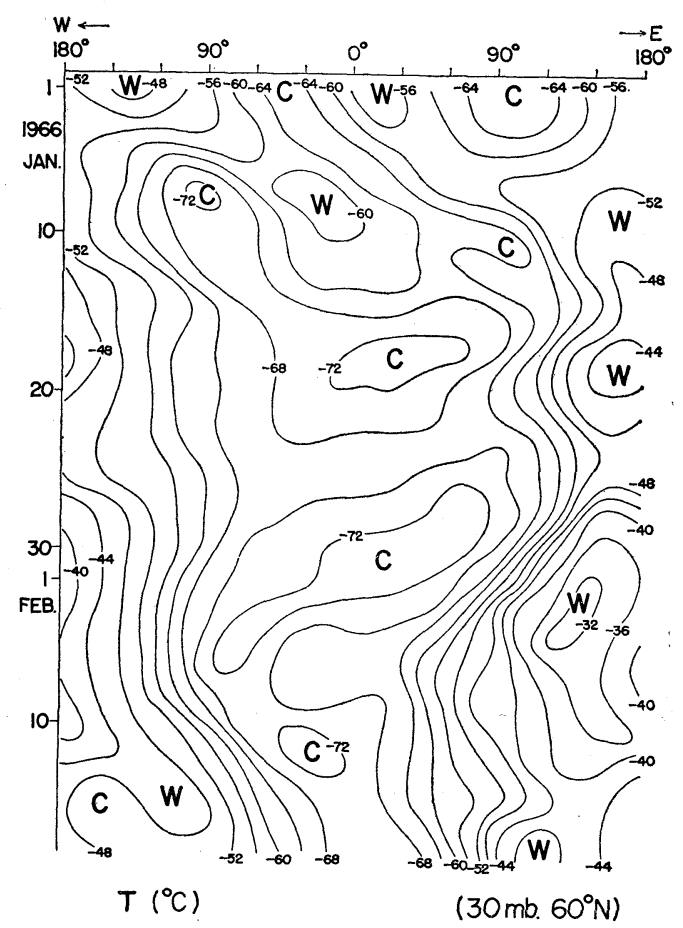

Fig. 8. Horizontal time section of temperature at the $30-\mathrm{mb}$ level along $60^{\circ} \mathrm{N}$. Units in ${ }^{\circ} \mathrm{C}$. 


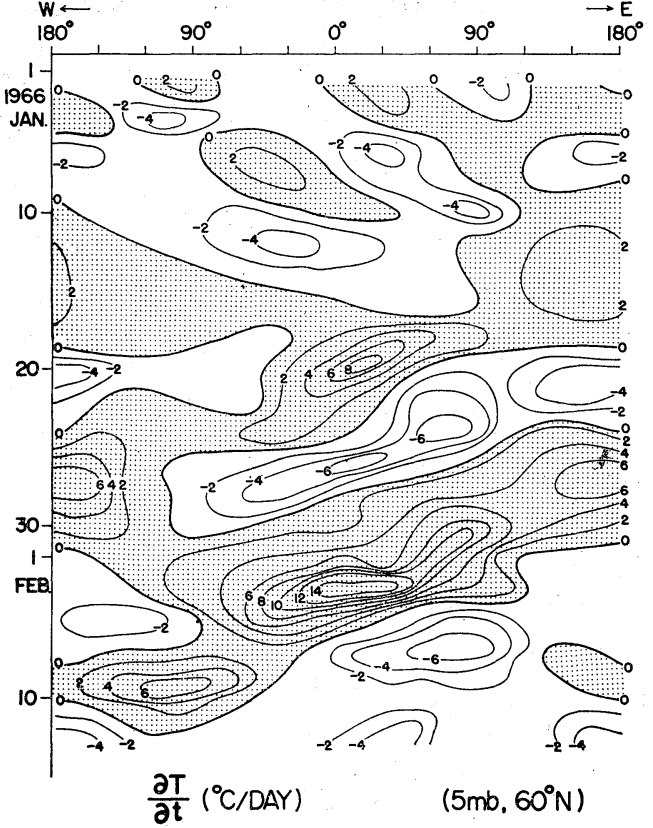

(a)

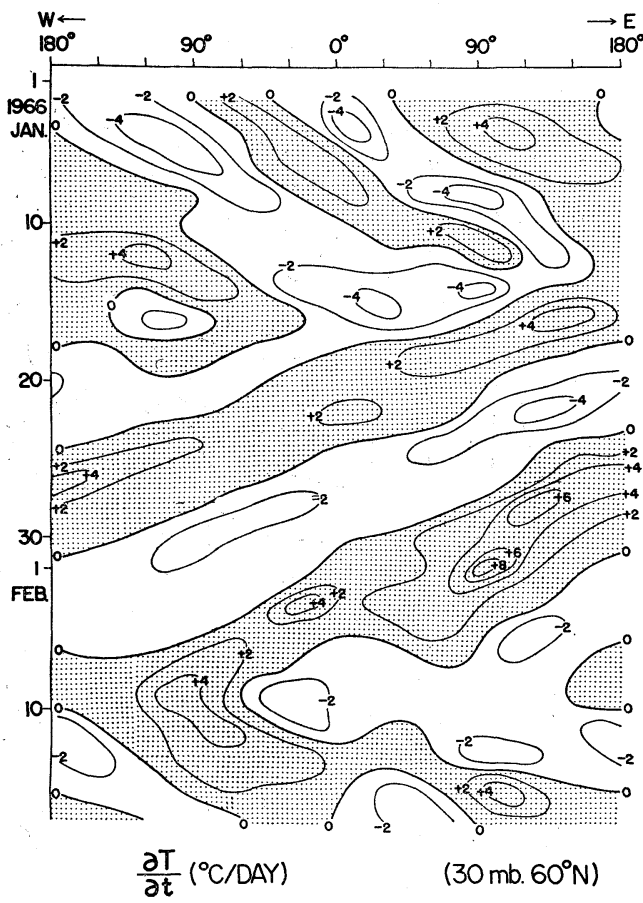

(b)

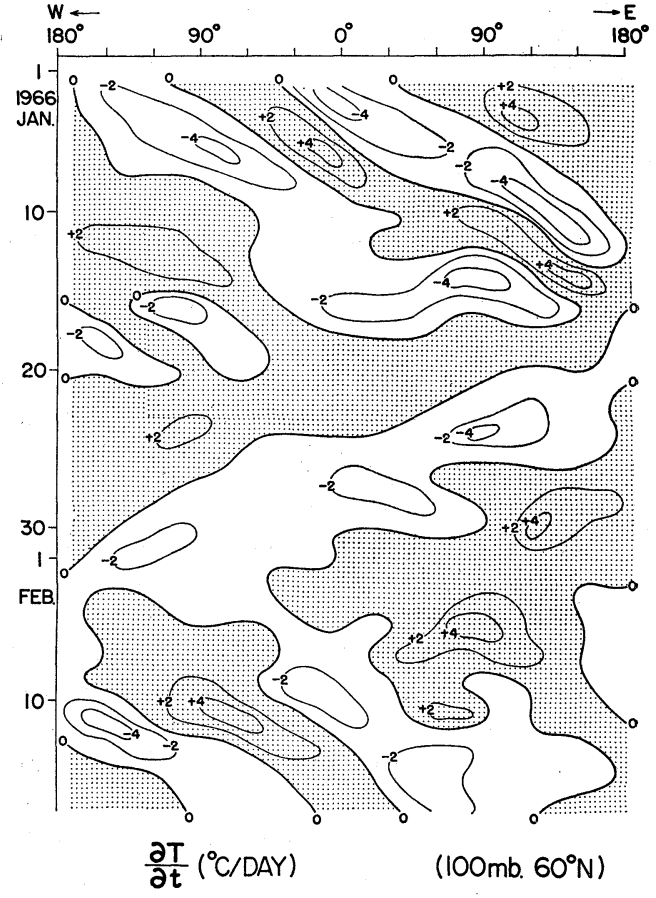

(c)

Fig. 9. Horizontal time sections of temperature change along $60^{\circ} \mathrm{N}$ for $5 \mathrm{mb}$ (a), $30 \mathrm{mb}(\mathrm{b})$ and $100 \mathrm{mb}$ (c). Units in ${ }^{\circ} \mathrm{C} /$ day. Shaded regions denote the temperature increase.

with that of temperature shown in Fig. $3 \mathrm{a}$ and $3 \mathrm{~b}$. This configuration suggests the existence of transient wave disturbances superposed on the quasi-stationary wave.

\section{Separation of transient waves}

We have shown the possibility of the existence of transient planetary waves superposed on the standing wave. In this section an attempt is made to separate the former from the latter by making the horizontal time sections of temperature and its time variation. First the horizontal time section of temperature at the $30-\mathrm{mb}$ level along $60^{\circ} \mathrm{N}$ is shown in Fig. 8, where the abscissa denotes longitudes and the ordinate the date from January to February. We can easily find in this fiugre a warm belt centered around $150^{\circ} \mathrm{E}$ and a cold belt around $0^{\circ}$, which are of course the same as those shown in Fig. 5.

One of the most interesting features in this time section is the longitudinal movement of the phase of temperature; for instance, the maximum 
(marked by W) moves eastward in the first half of January and in the middle of February, and then westward in the latter half of January and early February. This indicates the existence of traveling planetary waves in the stratosphere.

In order to bring out the traveling planetary waves more clearly, we have constructed the horizontal time sections of temperature change. We may assume that the time change of temperature due to the movement of transient waves is sufficiently large compared with that due to standing waves so that the temperature change may be mostly caused by traveling waves. Moreover if we assume a sinusoidal wave with a constant horizontal phase speed, the temperature change may appear as a sinusoidal wave with a phase lag of a quarter wavelength against the original temperature distribution. Fig. 9 shows the horizontal time sections of temperature change calculated from the differences between two days at the 5-, 30- and $100-\mathrm{mb}$ levels along $60^{\circ} \mathrm{N}$. The results of analysis are summarized in the following:

(1) In the first half of January, progressive waves of wave number two are observed in each level. The horizontal phase velocity is about $15^{\circ}$ (Long.) $/$ day $\fallingdotseq 10^{\circ}$ meter $/$ sec. Eastward traveling waves of wave number two are also observed after 10 February. In the second half of January a retrogressive wave of wave numbe one with a horizontal phase velocity of $-27^{\circ}$ (Long.)/day $\div-17$ meter/sec. is observed.

(2) The westward tilt of phase lines of temperature change with height is found for both types of traveling waves. A rough estimate of the tilting between the $5-\mathrm{mb}$ and $30-\mathrm{mb}$ levels for the wave of wave number one gives about $1 \mathrm{~km} / 3^{\circ}$ (Long.). Accordingly, the downward propagation of temperature phase shown in Fig. 3 is approximately explained as a result of the westward movement of the wave whose phase line is tilted westward with increasing height.

(3) Concerning the vertical distribution of the amplitude of temperature change, which is equivalent to that of temperature itself, it is found that the amplitude is nearly constant in the vertical for the wave number two and is strongly increasing with height for the wave number one.

(4) As for the maximum temperature increase on about 1 February, it is found that the "warming" first appears at the $100-\mathrm{mb}$ level around $120^{\circ} \mathrm{E}$ and then it propagates upward.

The results obtained in this analysis confirm the characteristics of transient planetary waves below 10mb given by the author (Hirota, $1967 \mathrm{~b}$ ) for the 1963 warming, and suggest that the structure and behavior of transient planetary waves in the upper stratosphere show similar features with those in the middle and lower stratosphere.

The next problem is to explain the nature of the traveling waves shown in the above analysis dynamically. The fact that the wave of wave number two moves eastward and the wave of wave number one retrogrades in the polar night westerlies suggests that, at least qualitatively, these waves are of Rossby type. But they cannot be regarded as neutral Rossby waves because the phase of these waves are tilted westward with increasing height. Then, are these a kind of baroclinic unstable waves? The theoretical studies on the ultra-long waves in a baroclinic zonal current (Green, 1960; Hirota, 1968) show, however, that the phase velocities of the unstable wave must be greater than the zonal velocity at the ground surface. Therefore the retrogression of the planetary wave in the polar night westerlies cannot yet been explained by the linear theory of free perturbations in a zonal current. Another possible explanation is that these traveling waves are forced ones, but it is also difficult to find a mechanism of forcing that produces traveling planetary waves in the stratosphere.

\section{Relationship between the zonal wind and distur- bances}

We have hitherto discussed the vertical structure and the time variations of large-scale wave disturbances in the midwinter stratospheric circulation. As was mentioned earlier, since we are interested in the dynamics of planetary waves in the stratosphere, a preliminary study is made in this section on other dynamical aspect of polar night westerlies throughout the period from January to February 1966.

Fig. 10 shows the vertical distribution of monthly mean zonal winds at $60^{\circ} \mathrm{N}$ in comparison with those in 1958 and 1963. The latter two cases are chosen because the explosive warmings 


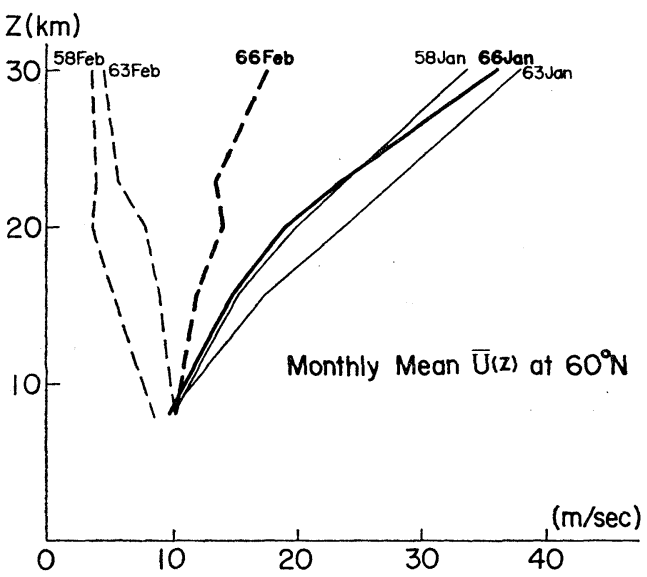

Fig. 10. Vertical distributions of monthly mean zonal wind at $60^{\circ} \mathrm{N}$ for three winter seasons of 1958,1963 and 1966.

took place in those winters at the end of January, on nearly the same date as the appearance of pronounced disturbances in 1966. It is found that the monthly mean zonal velocities of January in these three cases are very similar to each other both in wind velocities and in the vertical shear, whereas the monthly mean zonal wind of February in 1966 shows some difference from those of other two cases. Namely in the case of February 1966 the negative vertical shear is not observed except for the thin layer between 50 and $30 \mathrm{mb}$. The negative vertical shear in the higher latitudes means the reversal of northsouth temperature gradient caused by the northward sensible heat transport due to the development of planetary-scale disturbances in the stratosphere. Therefore the difference found in the mean zonal winds among these three cases in February indicates that the planetary waves in early 1966 are significantly weak in amplitude compared [with those appeared in the sudden warming of 1958 and 1963. This also means that we cannot detect the behavior of transient planetary waves only from the monthly mean zonal wind in January. Thus we next try to investigate the variation of zonal winds on the daily basis during the period of early 1966 .

Fig. 11 shows the interrelation between the day to day variation of the zonal wind and that of wave disturbances. In the lower part of Fig. 11 , the time section of mean zonal winds at four levels of $10,30,100$ and $300 \mathrm{mb}$ along $60^{\circ} \mathrm{N}$ is presented, where the ordinate indicates the zonal wind velocities measured in meter/sec. There are
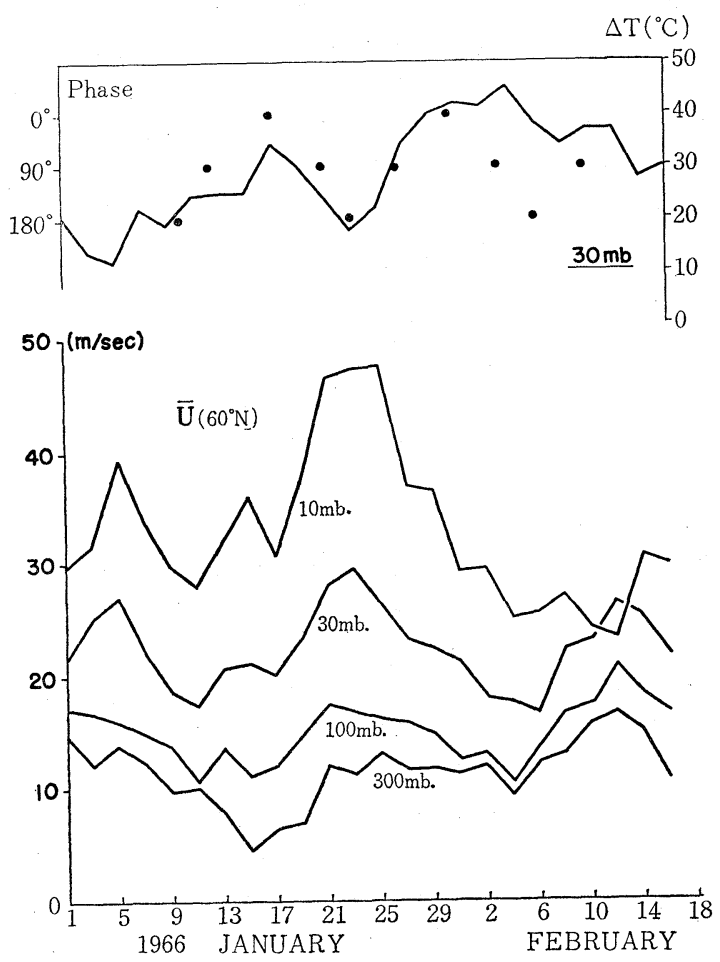

Fig. 11. Time sections of zonal winds at $60^{\circ} \mathrm{N}$ for $10,30,100$ and $300 \mathrm{mb}$. (lower) and of the maximum temperature difference along $60^{\circ} \mathrm{N}$ at the $30-\mathrm{mb}$ level (solid line; upper). Socild circles indicate the phase of traveling wave at $120^{\circ} \mathrm{W}$.

three peaks of westerly zonal winds around 5 and 23 January and 12 February. These three peaks correspond to the periods in which the traveling waves are predominant as was shown in Fig. 9. On the other hand, the maximum range of temperature difference, i.e., $T_{\max }$ minus $T_{m i n}$, along $60^{\circ} \mathrm{N}$ at the $30-\mathrm{mb}$ level is presented by the solid line in the upper part of Fig. 11. A significant negative correlation is found between the maximum temperature difference and the mean zonal velocities. This relation may be interpreted dynamically from two phases:

(1) Firstly, if we assume that the maximum temperature difference along $60^{\circ} \mathrm{N}$ shown in the upper part of Fig. 11 indicates the amplitude of the standing wave, the negative correlation mentioned above means that the upward propagation of planetary-scale disturbances is closely related to the zonal wind velocities as well as to its vertical shear. Namely the maximum amplitude of the 
standing wave is observed when the zonal wind is relatively weak, whereas the minimum amplitude is observed when the zonal wind is intense.

(2) Secondly, if we consider some dynamical interactions between the zonal current and the wave disturbances not only in terms of baroclinic process but also in terms of barotropic process, the gradual oscillation of the zonal velocity may be interpreted as a result of the energy conversion process between the zonal part and the eddy part associated with the manifestation of instability of the zonal current.

Concerning the dynamical instability of the polar night westerlies, however, we have to take account of the non-linear interaction between the standing wave and the transient wave. (Hirota, 1967a) Although we have shown the existence of transient (retrogressive) planetary waves in Fig. 9. the maximum temperature difference shown in Fig. 11 is not solely due to a simple superposition of the traveling wave on the standing wave. In the upper part of Fig. 11, the solid circles indicate the phase angle of traveling wave of wave number one measured at $120^{\circ} \mathrm{W}$. The phase angle of $0^{\circ}$ means that the temperature anomaly due to the traveling wave is maximum at $120^{\circ} \mathrm{W}$. If we choose another longitude to define the phase angle, then the position of solid circles must be shifted to the right or left. Now, we can easily find the positive correlation between the temperature anomaly at $120^{\circ} \mathrm{W}$ due to the traveling wave and the amplitude of temperature difference along $60^{\circ} \mathrm{N}$. Moreover, if we remember that the warm ridge of the standing wave is located around $150^{\circ} \mathrm{E}$ on the western portion of Aleutian High, it may be concluded that the maximum amplitude of the temperature anomaly along the latitudinal circle appears in such a situation that the phase difference of the waves of two types is a quarter of one wavelength. This conclusion confirms the theoretical result reached by the author in the previous study with use of a barotropic model (Hirota, 1967a), and therefore suggests the importance of nonlinear interaction between the standing wave and the transient wave in the stability property of the stratospheric circulation.

\section{Concluding Remarks}

Throughout the analysis of the structure and behavior of planetary waves in the stratosphere by the use of the MRN data together with the stratospheric synoptic charts, we have shown the evidence of planetary-scale disturbance in the upper stratosphere from various points of view. Although the conclusions obtained in the present study are not repeated here in detail, the result of analysis strongly suggests that the stratospheric circulation including planetary waves should be treated as a whole system from the lower to the upper stratosphere.

In this paper the synoptic charts in the upper stratosphere such as at the $2-\mathrm{mb}$ or $0.4-\mathrm{mb}$ level are not at all presented because of the sparsity of MRN data, but when we have much more data in future both in space and time the description of the planetary wave in the upper stratosphere based on harmonics analyses of synoptic charts will become possible.

Concerning the dynamics of planetary waves in the stratosphere, apart from the sudden warming phenomenon, the explanation of the behavior of transient waves in the polar night westerlies still remains to be a problem. Thus the diagnostic study of the waves based on the observations in the hemispheric scale should be made extensively together with the theoretical investigation of the stability property of the stratospheric circulation.

\section{Acknowledgments}

The author wishes to express his hearty thanks to Prof. S. Syōno of Tokyo University for his encouragement throughout this work. The author is deeply indebted to Prof. M. Yanai of Tokyo University and Dr. K. Miyakoda of GFDL, ESSA, who read the manuscript and gave the author many valuable comments. Thanks are also due to Dr. K. Labitzke of Free University of Berlin for her courtesy to supply him the meteorological rocket data of West Geirinish, and for her stimulative discussions in her staying at Tokyo in 1968. This research was partially supported by Funds of Scientific Research from the Ministry of Education. Thanks are extended to Mrs. M. Ishiguro for typewriting the manuscript.

\section{References}

Beyers, N.J., and B.T. Miers, 1965: Diurnal temperature change in the atmosphere between 30 and $60 \mathrm{~km}$ over White Sands Missile Range. J. atmos. Sci., 22, 262-266. 
Boville, B.W., 1966: Planetary waves in the stratosphere and their upward propagation. Space Research, 7, $20-29$.

Charney,J.G., and M.E. Stern, 1962: On the stability of internal baroclinic jets in a rotating atmosphere. J. atmos. Sci. 19, 159-172.

Craig, R.A., and W.S. Hering, 1959: The stratospheric warming of January-February 1957. J. Meteor., 16, 91-107.

Deland, R.J., and K.W. Johnson, 1968: A statistical study of the vertical structure of traveling planetaryscale waves. Mon. Wea. Rev., 96, 12-22.

Finger, F.G., S. Teweles, and R.B. Mason, 1963: Synoptic analysis based on meteorological rocketsonde data. J. geophys. Res., 68, 1377-1399.

Finger, F.G., and S. Teweles, 1964: The mid-winter 1963 stratospheric warming and circulation change. J. appl. Meteor., 3, 1-15.

Finger, F.G., H.M. Woolf and C.E. Anderson, 1966: Synoptic analyses of the 5-, 2-, and 0.4-millibar surfaces for the IQSY period. Mon. Wea. Rev., 94, 651-661.

Finger, F.G., and H.M. Woolf, 1967: Southern hemisphere stratospheric circulation as indicated by shipboad meteorological rocket observations. $J$. atmos. Sci., 24, 387-395.

Free University of Berlin, 1966: Daily northern hemisphere 5-, 10-, 30-, 50-, and 100-mb synoptic weather maps. Meteor. Abhandl., Band LXV, LXVI, LXVII, LXVIII, LXXXVIII, Heft. 1.

Green, J.S.A,. 1960: A problem in baroclinic stability. Quart. J. Roy. meteor. Soc., 86, 237-251.

Hirota, I., 1967a: Dynamic instability of the strato- spheric polar vortex. J. meteor. Soc. Japan, 45, 409-421.

, 1967b: The vertical structure of the stratospheric sudden warming. J. meteor. Soc. Japan, 45, 422-435.

- 1968: On the dynamics of long and ultralong waves in a baroclinic zonal current. $J$. meteor. Soc. Japan, 46, 234-249.

Labitzke, K., 1968: Midwinter warmings in the upper stratosphere in 1966. Quart. J. Roy. meteor. Soc., 94, 279-291.

Leovy, C., 1964: Radiative equilibrium of the mesosphere. J. atmos. Sci., 21, 238-248.

Matsuno, T. and I. Hirota, 1966: On the dynamical stability of polar vortex in wintertime. J. meteor. Soc. Japan, 44, 122-128.

Murray, F.W., 1960: Dynamic stability in the stratosphere. J. geophys. Res., 65, 3273-3305.

Reed, R.J., D.J. McKenzie, and J.C. Vyverberg, 1966: Diurnal tidal motions between 30 and 60 kilometers in summer. J. atmos. Sci., 23, 416-423.

Scherhag, R., 1952: Die explosionsartigen Stratosphärenerwärmungen des Spätwinters 1951-1952.

Ber. Deutsch. Wetterdienst., 6, 51-63.

Teweles, S., 1958: Anomalous warming of the stratosphere over North America in early 1957. Mon. Wea. Rev., 86, 377-396.

Warnecke, G., 1956: Ein Beitrag zur Aerologie der Arktischen Stratosphäre. Meteor. Abhandl., Band III, Heft 3, Freien Universität Berlin.

World Data Center A. Meteorology: Data Report Meteorological Rocket Network Firings. Vol. III, No. $1-4,1966$.

\title{
1966 年冬期に於ける上部成層圈のプラネタリー波
}

\author{
廣田勇 \\ 東京大学理学部地球物理学教室
}

1966年冬期に於ける上部成層圈のプラネタリー波に関して，その構造と変動を気象ロケット観測資料及び高層天気 図を用いて解析した。Fort Greely（アラスカ），Fort Churchill（カナダ）等に於ける温度の time section は成層圈 全層にわたる擾乱の存在を示し，又 $60^{\circ} \mathrm{N}$ に沿ら温度の cross section を作ってみるとこの擾乱は東西方向にひろが るプラネタリー波動であって温度と高度の位相はともに上方に行くにつれて西に傾いていることがわかる。6 $60^{\circ} \mathrm{N} に$ 沿う温度の時間变化を見ることによって定常波と移動波との分離が可能であり，波数 2 の波の東進，波数 1 の波の西 進が示される。锭って1点での time section に見られる温度位相の下向き伝播は，西に傾いた波の西進の結果と見 なされる。最後に非定常波のふるまいと平均帯状流の時間变動との相互関係を極夜偏西風の安定性の見地から考察 した。 